\title{
MI TÖRTÉNIK A FÖLD LEGMAGASABBAN FEKVŐ SIVATAGÁNAK ALJZATÁBAN? AZ AKTÍV RÉTEG HÖMÉRSÉKLETI ELEMZÉSE A SZÁRAZ-ANDOKBAN
}

\author{
Nagy Balázs ${ }^{(1)}$, Kovács József ${ }^{(2)}$, Ignéczi Ádám ${ }^{(3)}$, Beleznai Szabolcs ${ }^{(4)}$, \\ Mari László ${ }^{(1)}$, Szalai Zoltán ${ }^{(5)}$ \\ ${ }^{(1)}$ ELTE Természetföldrajzi Tanszék \\ ${ }^{(2)}$ ELTE Általános és Alkalmazott Földtani Tanszék \\ ${ }^{(3)}$ Department of Geography, University of Sheffield, UK \\ ${ }^{(4)}$ BME Atomfizika Tanszék \\ ${ }^{(5)}$ ELTE Környezet- és Tájföldrajzi Tanszék
}

\section{Bevezetés}

A d.sz. $28-22^{\circ}$ között Chile és Argentína területén húzódó Puna de Atacama magasföld - a Száraz-Andok részeként - a Föld egyik legextrémebb környezete. Az „andoki száraz átló” mentén elhelyezkedve rendkívül száraz régió, kevés csapadékkal és magas evaporációval (Messerli et al., 1997; Vuille \& Amann, 1997; Ahumada, 2002; Kull et al., 2002; Houston \& Hartley, 2003). A felföld átlagos tengerszint feletti magassága $4000 \mathrm{~m}$ (Clapperton, 1994; Ahumada, 2002), területén számos óriásvulkán emelkedik. Ezek legnagyobbika a 6893 m magas alvó vulkáni komplexum, az Ojos del Salado (2706’34.6” D, 68³2’32.1” Ny).

E régióban van a Földön - az extrém hideg és száraz klíma miatt - a legmagasabban az egyensúlyi vonal (7000 m környékén, Clapperton, 1994; Kull et al., 2002). Az aktív jégborítás nem jellemző, a felszín alatt mégis jelen van a jég, erre a periglaciális felszínformák és a permafroszt-modellezések eredményei is rámutatnak (Corte, 1982; Trombotto, 2000; Ahumada, 2002; Gruber, 2012; Azócar et al., 2017). Az alacsony csapadékmennyiség, a magas evaporáció és a gleccserek korlátozott jelenléte miatt a permafrosztban levő jég - mint a krioszféra legjelentősebb itteni formája -, igen jelentős szerepet játszhat a térség hidrológiájában és ökológiájában (Grosjean \& Veit, 2005; Azócar \& Brenning, 2010; Aszalós et al., 2016). A térségben azonban - a sziklagleccsereken kívül - eddig nem zajlott szisztematikus felszín alatti hőmérsékleti monitoringvizsgálat.

Alapvető célunk, hogy feltárjuk a regolitban levő jég jelenlétét sekély mélységekben telepített hőmérsékletmérő eszközökkel. A hőmérsékleti adatsorok vizsgálata során különösen nagy hangsúlyt fektetünk az aktív rétegben zajló folyamatok elemzésére, mivel ez az időszakosan felengedő réteg lehet a nedvesség jelenlétének, áramlásának helyszíne. Ahhoz, hogy mindezt megtehessük, 2012-ben hosszú távú mérési programot indítottunk az Ojos del Salado chilei oldalán. Nyilvánvalóvá vált, hogy a permafroszt aljzat 5000 méter fölött jelen van, ugyanakkor egyedülálló különlegesség, hogy a permafroszt területeket sivatagi környezet uralja, a klasszikus periglaciális jelenségek háttérbe szorulnak. Ebböl a szempontból az $5600 \mathrm{~m}$ fölötti magashegyi zóna a legérdekesebb, mely egyben a Föld legmagasabban elhelyezkedő sivatagi helyszíne is.

\section{Felszín alatti hőmérsékletmérés}

A regolit hőmérsékletének mérése - 4200 és 6893 m között - hat helyszínen történik (1.áb$\mathrm{ra}$ ), a legtöbb ponton $10 \mathrm{~cm}, 35 \mathrm{~cm}$ és $60 \mathrm{~cm}$ mélységben. A kivételt csak a legmagasabban elhelyezkedő két mérőhely jelenti, mivel ott az aktív réteg mélysége mindössze 10-20 cm. 


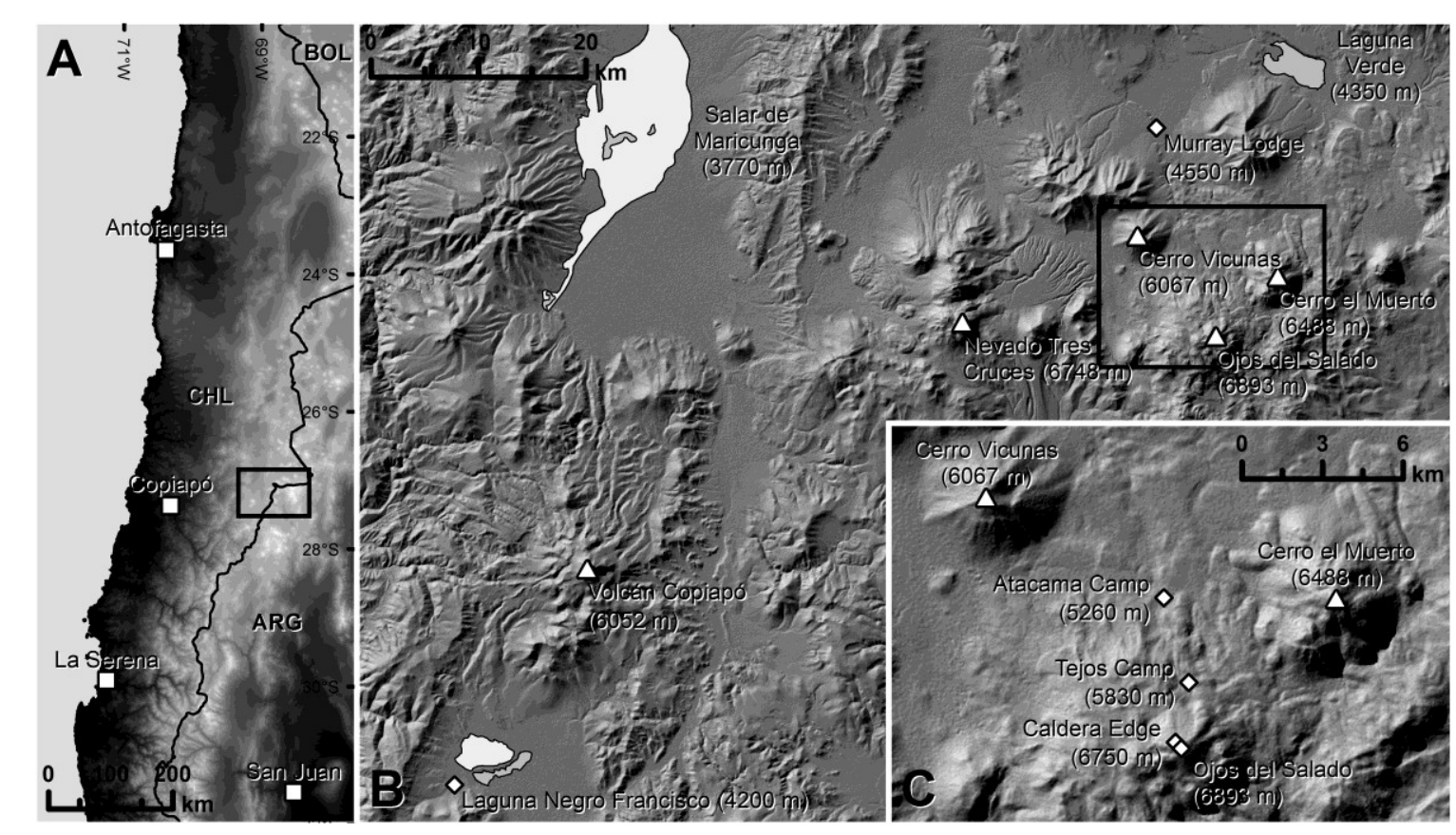

1. ábra: A tanulmányozott terület mérési helyei (csúcsára állított fehér négyszög), a nagyobb vulkáni csúcsok (fehér háromszög), sós tavak (sötétszürke poligonok) és sósivatagok (világos szürke poligonok) SRTM (Shuttle Radar Topography Mission) V.3.0 domborzat-árnyékolásos térképen.

A hőmérsékletét HOBO Pro v2 (mérési tartomány: $-40{ }^{\circ} \mathrm{C}-70{ }^{\circ} \mathrm{C}$, pontosság: $\pm 0,21{ }^{\circ} \mathrm{C}$ ) adatgyüjtő eszközök rögzítik óránként. Az Ojos del Salado csúcsán HOBO U23 Pro-val (mérési tartomány: $-40{ }^{\circ} \mathrm{C}-70{ }^{\circ} \mathrm{C}$, pontosság: $\pm 0,21^{\circ} \mathrm{C}$ ) léghömérséklet mérésre is sor kerül. Az Andokból nincsenek 5850 m-nél magasabbról rövidtávú (Schröder \& Schmidt, 2000), illetve 4700 m-nél magasabbról hosszú távú (Schrott, 1991; Happoldt \& Schrott, 1992) regolit hőmérséklet mérések. Észleléseink így a legmagasabban fekvő in situ hosszú távú mérések, melyek felvilágosítást adhatnak a regolit besugárzáshoz kapcsolódó viselkedéséről.

A monitoringvizsgálat során a hőmérsékletmérések kiegészülnek a regolit fizikai tulajdonságainak meghatározásával (szemcseméret eloszlás, porozitás és higroszkóposság), hiszen ezek meghatározzák a víz- ill. jégtartó képességet és a vízáramlást, de jelentősen befolyásolják a periglaciális felszínformák kialakulását is. E tulajdonságok ismerete jelentős mértékben támogatja a mért hőmérséklet-idősorok értelmezését.

A permafrosztban a felszín alatti hömérséklet legalább két egymást követő évben $0{ }^{\circ} \mathrm{C}$ alatt marad (van Everdingen, 2005), így az itteni hőmérséklet mérése a permafroszt vizsgálatának fontos és széles körben használt eszköze (e.g. Schrott, 1991; Grab et al., 2004; Andrès et al., 2011; Otto et al., 2012; Li et al., 2014). Az aktív réteg a permafroszt fölött helyezkedik el, benne évente megfigyelhetők a fagyás-olvadás folyamatai (van Everdingen, 2005). Ha az üledékben jelen van víz jég és a hömérséklet eléri a $0{ }^{\circ} \mathrm{C}$-ot, egyensúlyi állapot áll be. Ennek oka, hogy az elnyelődött energia nem a hőmérséklet csökkenésre, illetve emelkedésre, hanem az anyag molekuláris szerkezetének megváltoztatására fordítódik, ami a halmazállapot-változásban nyilvánul meg (látens hő). Ekkor a hőmérséklet napi periodikus ingadozása elmarad, megvalósul a zéró-függöny jelenség (zero curtain effect) Tehát, ha a regolithőmérséklet állandósulását a víz olvadáspontjánál figyeljük meg és az egyéb vízforrások (pl. hótakaró, évelő hó/firn foltok) jelenléte kizárható, a nedvesség forrása nagy valószínüséggel az olvadó/megfagyó talajjég (Romanovsky \& Osterkamp, 2000; Hanson \& Hoelzle, 2004).

A hóborítottság - szigetelő hatása miatt - ugyanakkor jelentős mértékben befolyásolhatja a regolit hőmérséklet-változásának dinamikáját (pl. Ishikawa, 2003). A vizsgált terület extrém száraz környezet, ahol a hófedettség vékony, a szélnek és a szublimációnak köszönhetően víz- 
szintes elterjedtsége nem folytonos (Kull et al., 2002; Houston \& Hartley, 2003; Ginot et al., 2006; Houston, 2006; Espinoza et al., 2015). Így a hótakaró szigetelő hatása a vizsgált terület egészére nézve alcsonynak tekinthető (pl. Harris \& Brown, 1978; Ishikawa, 2003). Vizsgálatainkhoz elvégeztük a térség hóborítás-változásának elemzését is (a Landsat és MODIS adatbázisok felhasználásával).

\section{A hőmérséklet-idősorok feldolgozásának módszerei}

Számítottuk a napi átlagos talajhőmérsékleteket (NÁTH) és a talajhőmérsékletek napi ingásait (THNI) az órás hőmérsékletek mért értékeiből, mely utóbbiak az egyes naptári napok maximális és minimális hőmérséklet értékei közötti különbségeket jelentik. Ezek a számítások minden hőmérséklet regisztráló müszer teljes adatgyüjtési időtartamára elkészültek. Átlagos havi talajhőmérsékletet (ÁHTH) naptári hónapokra számoltunk, átlagos éves talajhőmérsékletet (ÁÉTH) pedig 365 NÁTH átlagaként 2012. február 23-tól kezdődően.

Annak ellenére, hogy a permafroszt jelenléte egyértelműen látszik az NÁTH és THNI idősorokból, zéró függöny jelenséget nehezen lehetett meghatározni. Ezért, hogy ezt segítsük és megtámogassuk a felszínalatti jég jelenlétére vonatkozó megállapításaink megbízhatóságát, idősorainkra wavelet transzformációt alkalmaztunk

$$
W_{n}(s)=\sum_{n=0}^{n} X_{n}^{\prime} \Psi^{*}\left[\frac{\left(n^{\prime}-n\right) \delta t}{s}\right],
$$

ahol a '*' komplex konjugált, ' $X_{n}$ ' eredeti adat, 's' skála, ' $\Psi$ ' wavelet függvény, ' $\delta$ ' felbontás mértéke A módszer idő-frekvencia felbontást eredményez, és alkalmazásával lehetővé válik, hogy egy adott jelnek időben változó jellegzetességeit megragadjuk (Daubechies, 1990; Torrence \& Compo, 1998; Kovács et al., 2010). Így lehetőségünk adódik arra, hogy becsüljük a napi periodicitás jelenlétét, illetve annak „erejét” a mért hőmérsékletek idősoraiban, ami várhatóan alacsony vagy hiányzik a felszínalatti jég fagyási/olvadási hömérsékletének környékén, köszönhetően a zéró függöny hatásnak. A napi periodikus ingadozás jelenlétének meghatározásához az éves nagyságrendủ ingadozást az idősorból eltávolítottuk, mivel azok elfedhetik a napi periodicitás „észlelését”. Első lépésként 24 órás mozgóátlagot vontunk ki a mért idősorokból és a kapott maradékokra wavelet transzformációt alkalmaztunk, Morlet függvénnyel (2. ábra). A számítások R-ben készültek, dplR 1.6.4. program csomaghasználatával (Torrence \& Compo, 1998; Kovács et al., 2010).

\section{Hőmérséklet-modellezés}

A felszín alatti hőmérséklet időbeli változását végeselem módszeren alapuló modellezéssel is vizsgáltuk. Ez a hőtani modell a hővezetés differenciálegyenletével számítja a felszín alatt a hőmérséklet időbeli változását, figyelembe véve a felszíntől különböző mélységben levő monitoring pontok környezetének anyagi összetételét, a felszíni hömérséklet alakulását és a víz/jég halmazállapot változását.

A modell azt a feltételezést tartalmazza, hogy folyadék állapotban nincs keveredés, ezért nem kell figyelembe venni a keveredés nyomán bekövetkező sürüségváltozásokat. A modellben használt hővezetési differenciálegyenlet:

$$
\rho C \frac{\partial T}{\partial t}+\nabla(-k \nabla T)=Q
$$

ahol $\varrho\left(\mathrm{kg} / \mathrm{m}^{3}\right)$ a sürüség, $C(\mathrm{~J} / \mathrm{kg} \cdot \mathrm{K})$ átlagos hőkapacitás állandó nyomáson, $k$ átlagos hővezetési tényező $(\mathrm{W} / \mathrm{m} \cdot \mathrm{K}), T$ hömérséklet $(\mathrm{K})$, és $Q$ hő forrástag $\left(\mathrm{W} / \mathrm{m}^{3}\right)$. 


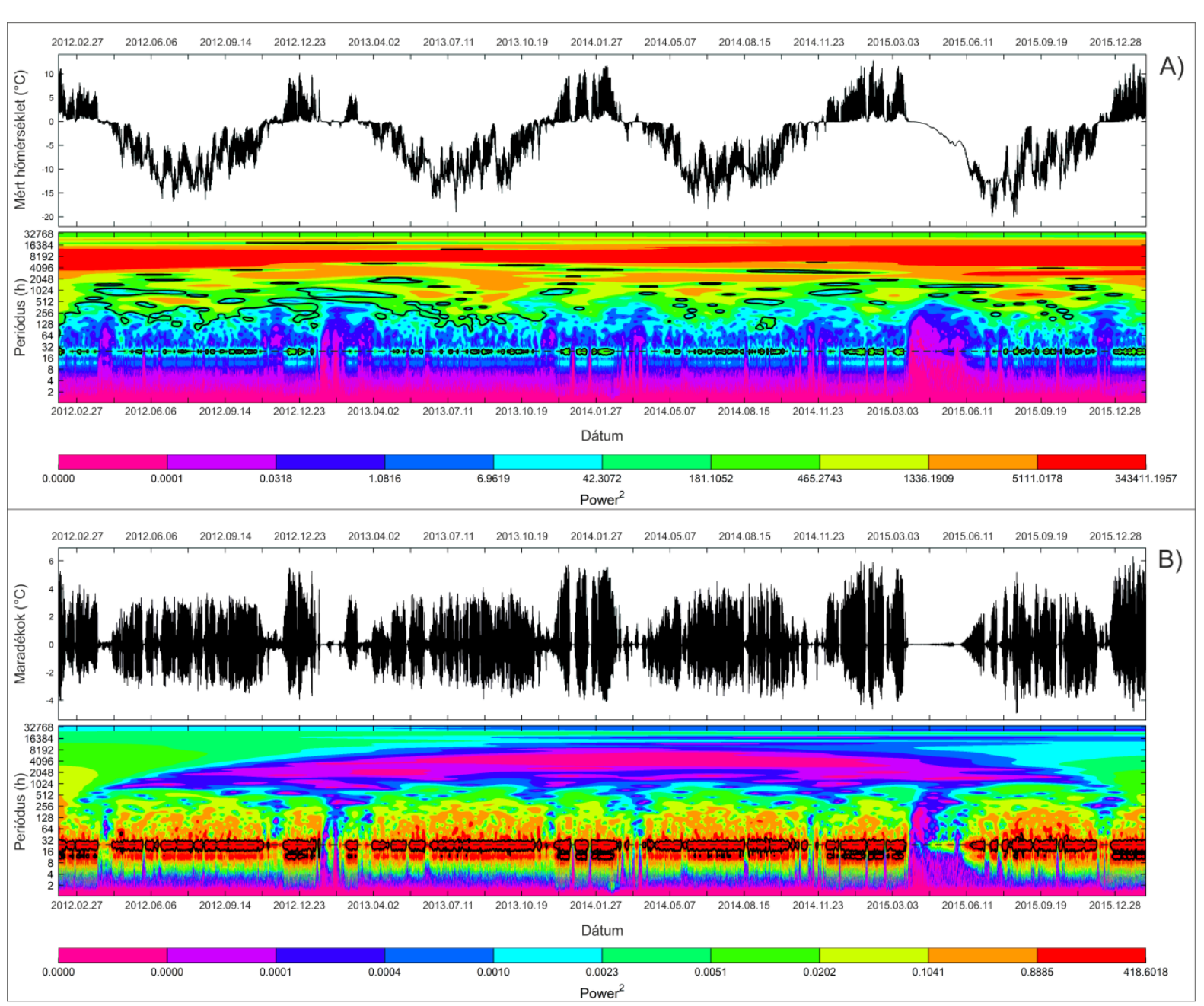

2. ábra: Az 5830 m-en elhelyezkedő Tejos mérőhelyszín 10 cm-es mélységében mért hőmérséklet és az ebből készült wavelet spektrum becslés (A), mért adatok és 24 pontos mozgóátlag-különbségeként kapott maradék, valamint a belöle készült wavelet spektrum becslés (B) eredményei.

A modellben a kőzet fizikai tulajdonságait andezitre vonatkozó fizikai állandókkal jellemeztük és mivel abban porozitástól, mélységtől és hőmérséklettől függően különböző arányban vannak jelen az egyes alkotó elemek, ,két kevert összetételü” anyag felhasználására került sor (jég-kőzet-levegő, illetve víz-kőzet-levegö).

A modell tartalmazza azt a közelítést, hogy minden időpillanatban lokális termikus egyensúly áll fenn a különböző anyagi komponensek - víz, kőzet és levegő - között. Ezért a komponensek termikus viselkedését leíró fizikai anyagparaméterek - sürüség, hővezetési tényező, hökapacitás - leírhatók átlagos, származtatott mennyiségekkel, melyeket a komponensek térfogat arányaiból számolunk, súlyozott átlaggal. A hőtani tulajdonságok függnek a kompozit anyag összetételétöl. A modell egyik peremfeltétele a $-10 \mathrm{~cm}$-en mért hömérséklet, míg a másik a $-5 \mathrm{~m}$-en, állandó $-2,5^{\circ} \mathrm{C}$ hőmérséklet volt.

\section{Az aktív réteg termális viselkedése az Ojos del Salado környezetében}

A leíró statisztikák és a napi átlagos talajhőmérsékletek éves eloszlása alapján a permafrosztot nem lehetett közvetlenül észlelni a Laguna Negro Francisco (4200 m t.sz.f.), Murray Lodge (4550 m t.sz.f.) és az Atacama Camp (5260 m t.sz.f.) mintavételi helyszíneken, így az aktív réteg jelenléte a legmagasabb hegyi zónára korlátozódik. 

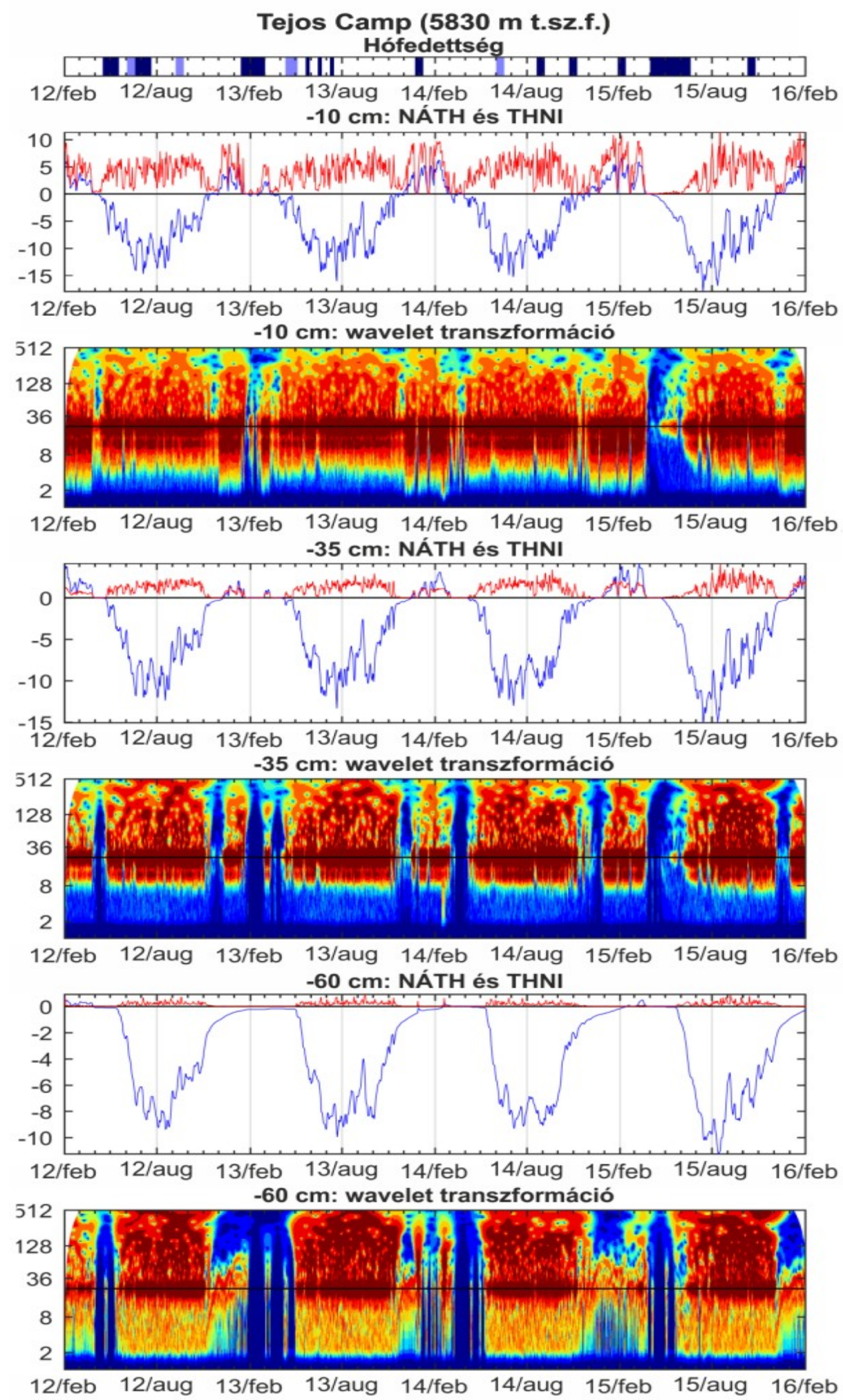

3. ábra: Hófedettség (világoskék: részleges hófedettség; sötétkék: teljes hófedettség), napi átlagos talajhőmérsékletek (NÁTH, kék folytonos vonal), talajhőmérséklet napi hőingása (THNI, vörös folytonos vonal) és a hőmérsékletadatok wavelet transzformációjának eredménye (meleg színek: periodicitás jelenléte erős; hideg színek: gyenge, illetve hiányzó periodicitás) a Tejos mérőhelyszínen, 5830 m-en. A 24 órás periódusidő folytonos fekete vízszintes vonallal az y tengelyen kiemelve a wavelet transzformáció eredménye panelen. A meleg színek ezen vonal mentén jelzik az egynapos periódus jelenlétét, míg a hideg színek a gyengén kimutatható periodicitást, vagy annak teljes hiányát mutatják. 
A 2012 és 2016 között mért hőmérséklet idősorból megerösíthető a permafroszt jelenléte a Tejos Camp esetében (5830 m t.sz.f.). Ez a tény és a rendelkezésre álló idősorok hossza lehetővé tette, hogy részletes vizsgálat alá vessük a Tejos Camp mintavételi pont három mélységben mért hőmérséklet adatait, hogy részletekbe menő ismereteket kapjunk az aktív réteg viselkedéséröl (3. ábra).

A Tejos-helyszín mérési és a napi periodikus viselkedés jelenlétére vonatkozó számítási eredményeket összegezve megállapítható, hogy a $60 \mathrm{~cm}$-es mélységben levő hőmérsékletmérő közel volt elásva a permafroszt tetejéhez és az aktív réteg aljához. A napi átlagos talajhőmérséklet hosszú időtartamokon keresztül nagyon közel volt $0{ }^{\circ} \mathrm{C}$-hoz és ritkán emelkedett $0{ }^{\circ} \mathrm{C}$ fölé. A zéró függöny - a felszíni hóborítottságtól függetlenül - minden nyáron megjelent a Tejos-méröhely ezen mélységén. A zéró függöny jelenség ugyanakkor $35 \mathrm{~cm}$ mélységben is jelen volt, de csak rövid időre, minden nyár elején és végén, körülbelül egy hónapig. $10 \mathrm{~cm}$-es mélységben a felszín alatti hőmérséklet napi hőingása egész évben magas volt, kivételt a terület hóval fedett időszaka és a halmazállapot változás időszaka képzett.

A nyári félévben a napi periodikus ingadozás 35 és $60 \mathrm{~cm}$-es mélységekben, különböző hőmérsékleten, a zéró függöny jelenség megjelenése előtt hosszabb időre elmaradt. A nyárból a télbe tartó lehülés során, ellentétben a felmelegedés során tapasztaltakkal, a hőmérséklet napi periodikus ingadozása már a $0{ }^{\circ} \mathrm{C}$ közelében megjelenik.

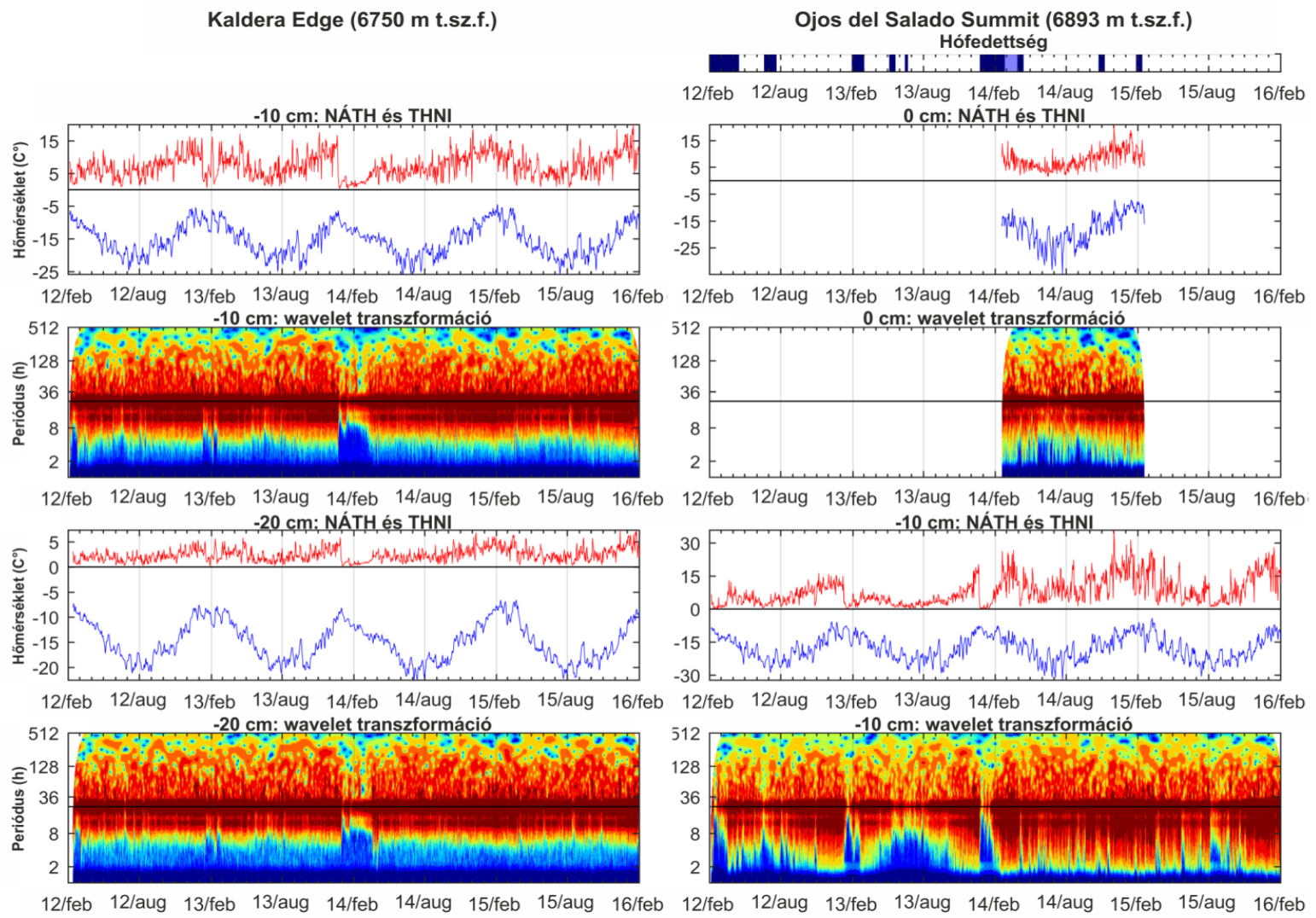

4. ábra: Hófedettség (világoskék: részleges hófedettség; sötétkék: teljes hófedettség), napi átlagos talajhőmérsékletek (NÁTH, kék folytonos vonal), talajhőmérséklet napi hőingása (THNI, vörös folytonos vonal) és a hőmérséklet adatok wavelet transzformációjának eredménye (meleg színek: periodicitás jelenléte erős; hideg színek: gyenge, illetve hiányzó periodicitás) a Caldera Edge és az Ojos del Salado Summit mérőhelyeken. A 24 órás periódusidő folytonos vízszintes fekete vonallal az y tengelyen kiemelve a wavelet transzformáció eredménye panelen. A meleg színek ezen vonal mentén jelzik az egynapos periódus jelenlétét, míg a hideg színek a gyengén kimutatható periodicitást, vagy annak teljes hiányát mutatják. 
A talajhőmérséklet napi hőingása $-10 \mathrm{~cm}$-en viszonylag magas volt, kivéve a hóval fedett 2013 januári és 2015 áprilisi időszakokat. A zéró függöny eseményeket azonban $-35 \mathrm{~cm}$-en 1-2 hónapig minden nyár kezdetén és végén meg lehetett megfigyelni, $-60 \mathrm{~cm}$-en pedig minden nyáron folyamatosan jelen volt - jelezve a nedves feltételek jelenlétét. Ezek az események nem kapcsolódtak hófedettséghez, így azt feltételezzük, hogy a víz forrása az olvadó jég, ami ezekben az időszakokban nedvesen tartja az üledékek mélyebb rétegeit.

Az Ojos del Salado legmagasabb övezetében hőmérséklet méréseink alapján a permafroszt nagyon közel van a felszínhez. A Caldera Edge méröhelyen (6750 m t.sz.f.) a permafroszt $-10 \mathrm{~cm}$ fölött van, míg a föcsúcson (6893 m t.sz.f.) az óránkénti felszíni hőmérsékletek csak néha érték el a $0{ }^{\circ} \mathrm{C}$-ot, így a permafroszt nem lehet mélyebben, mint pár $\mathrm{cm}$. Tehát az aktív réteg ezeken a területeken rendkívül vékony.

A felszín alatti hőmérséklet változékonysága igen magas, olvadást nem lehetett megfigyelni. A regolithömérséklet-ingadozás csak akkor változik meg, ha hó fedi a területet, ilyen volt 2013 februárja és 2014 februárja (4. ábra).

A felszínközeli rétegek $10-20 \mathrm{~cm}$ mélységig az év egésze során pórusjég-mentesek. A szárazság miatt nem fagynak össze a kőzetszemcsék, ugyanakkor az üledék hőmérséklete végig rendkívül alacsony. A maximális napi átlagos talajhőmérséklet a Caldera Edge méröhelyen $10 \mathrm{~cm}$ mélységben $-4,5^{\circ} \mathrm{C}$, míg a föcsúcson $-7{ }^{\circ} \mathrm{C}$ volt.

\section{A hőmérséklet-modellezés eredményei a Tejos mérőhelyszínen}

A modell számára bemenő adat a $-10 \mathrm{~cm}$-en mért hőmérséklet-idősor volt és ebből történt becslés a -35 és a $-60 \mathrm{~cm}$-es mélységekre. A modelleredmények közül kiemelendő a halmazállapot index, aminek értéke 0 , ha a modell szerint a halmazállapot víz, 1 , ha a modell szerint a halmazállapot jég (5. ábra).

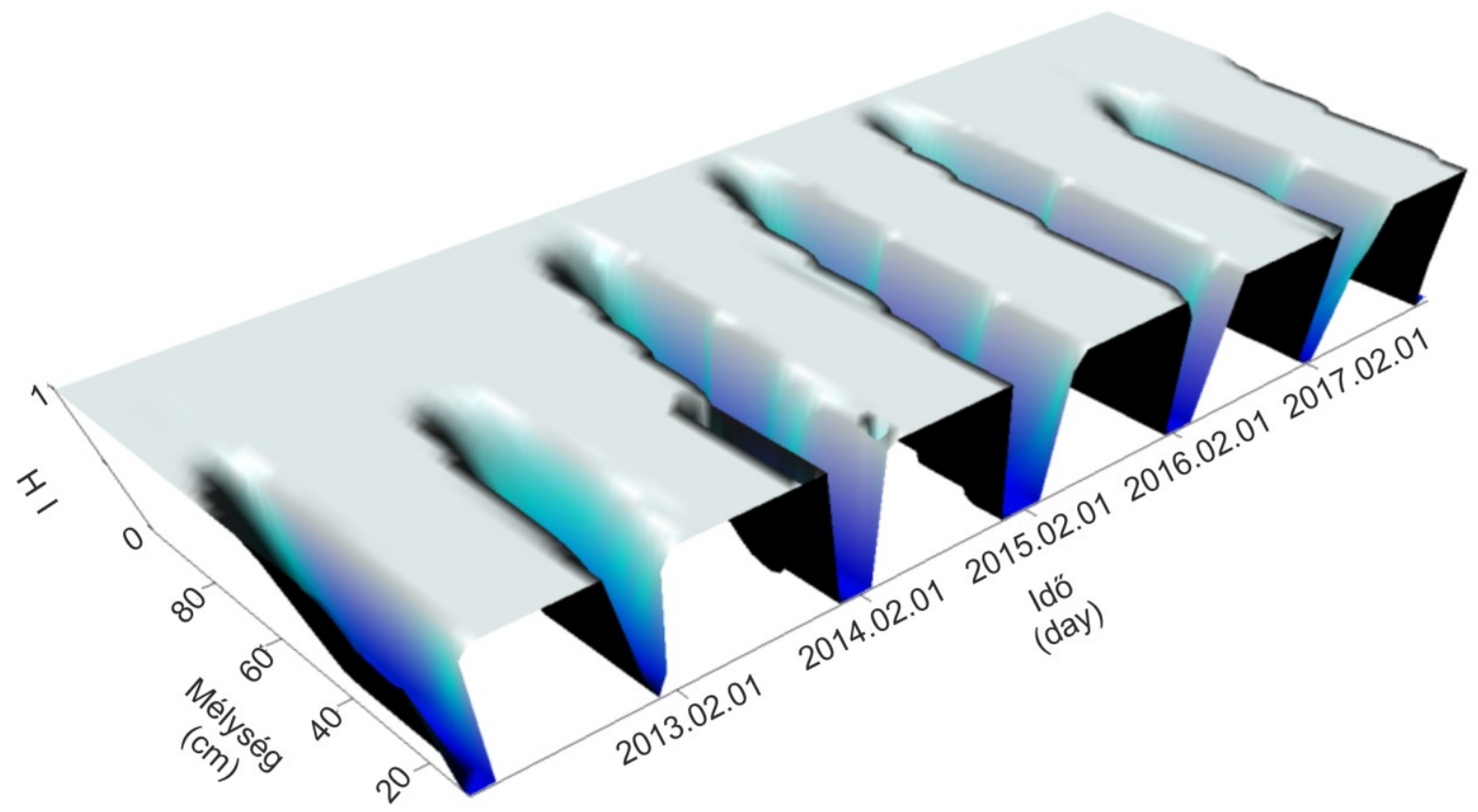

5. ábra: A halmazállapotot leíró index 3D megjelenítése, 2012.02.03 - 2018.02.02 között, $100 \mathrm{~cm}$ mélységig (kék: víz, halmazállapot index értéke 0 ; világosszürke: jég, halmazállapot index értéke 1). 
A napi periodikus ingadozással rendelkező napok számának aránya a teljes vizsgált időtartamban a mért és modellezett idősorokban, $35 \mathrm{~cm}$-es mélységben 5\%-os, $60 \mathrm{~cm}$-es mélységben 2,8\%-os különbséget mutatnak (1. táblázat).

1. táblázat: Napos periodikus ingadozás jelenléte százalékban, a vizsgált időtartam egészéhez képest mért és modellezett idősorokban, 2012.02.04-2016.02.02. között.

\begin{tabular}{|c|c|c|}
\hline Mélység (cm) & Mért (\%) & Modellezett (\%) \\
\hline 35 & 67.0 & 62.0 \\
\hline 60 & 49.0 & 51.8 \\
\hline
\end{tabular}

A napi átlagos hőmérsékletek esetében a számított hibák a mélységgel növekvő tendenciát mutatnak (2. táblázat). $-35 \mathrm{~cm}$-en, hülési folyamat során a modellezett hőmérsékletek alatta maradnak a mérteknek. Nyáron a modell a mért adatokkal jól egyezően $0{ }^{\circ} \mathrm{C}$ feletti hőmérsékleteket becsült. Ekkor a folyadék halmazállapot jellemző, ami a vizsgált időtartam 28,2\%ában volt jelen. $-60 \mathrm{~cm}$-en a hőmérséklet csökkenésének időszakában (jellemzően ősszel) a modell becsült értékei a mért hőmérsékletek alatt figyelhetök meg. A hőmérséklet növekedése során (jellemzően tavasszal) a modellezett értékek általában jól közelítik a mérteket, kivételt a mért hőmérsékleteknek -2-től $0^{\circ} \mathrm{C}$ közötti tartománya jelent, ahol a mért értékek a modell által túlbecsültek. Ennek mértéke megközelítheti az $1{ }^{\circ} \mathrm{C}$-ot. A nyári időszakokban a modellezés eredményeiben itt is megjelennek pozitív értékek és ezzel együtt a halmazállapot-változás is bekövetkezik. Ez jellemző a vizsgált időtartam 13,2\%-ában.

2. táblázat: Napi átlagos hőmérséklet becslésének abszolút és relatív hibái, mért és modellezett idősorokban 2012.02.04-2016.02.02. között.

\begin{tabular}{ccc}
\hline Mélység $(\mathrm{cm})$ & Abszolút hiba $\left({ }^{\circ} \mathrm{C}\right)$ & Relatív hiba (\%) \\
\hline 35 & 0.58 & 16.2 \\
60 & 1.451 & 43.3 \\
\hline
\end{tabular}

A hőtani modell eredménye szerint a halmazállapot változás, szilárd fázisból a folyadék fázisba $60-80 \mathrm{~cm}$ mélyen következik be, időben nem szimmetrikus folyamatként. A nyári felmelegedés során a halmazállapot változás az olvadás felé lassabban halad egyre mélyebbre, míg a szilárd fázisba történő átalakulás kissé gyorsabb. Eredmények szerint $-35 \mathrm{~cm}$-en december közeptől április második feléig, míg $-60 \mathrm{~cm}$-en január utolsó napjaitól április végéig van folyadék fázis (6. ábra). 


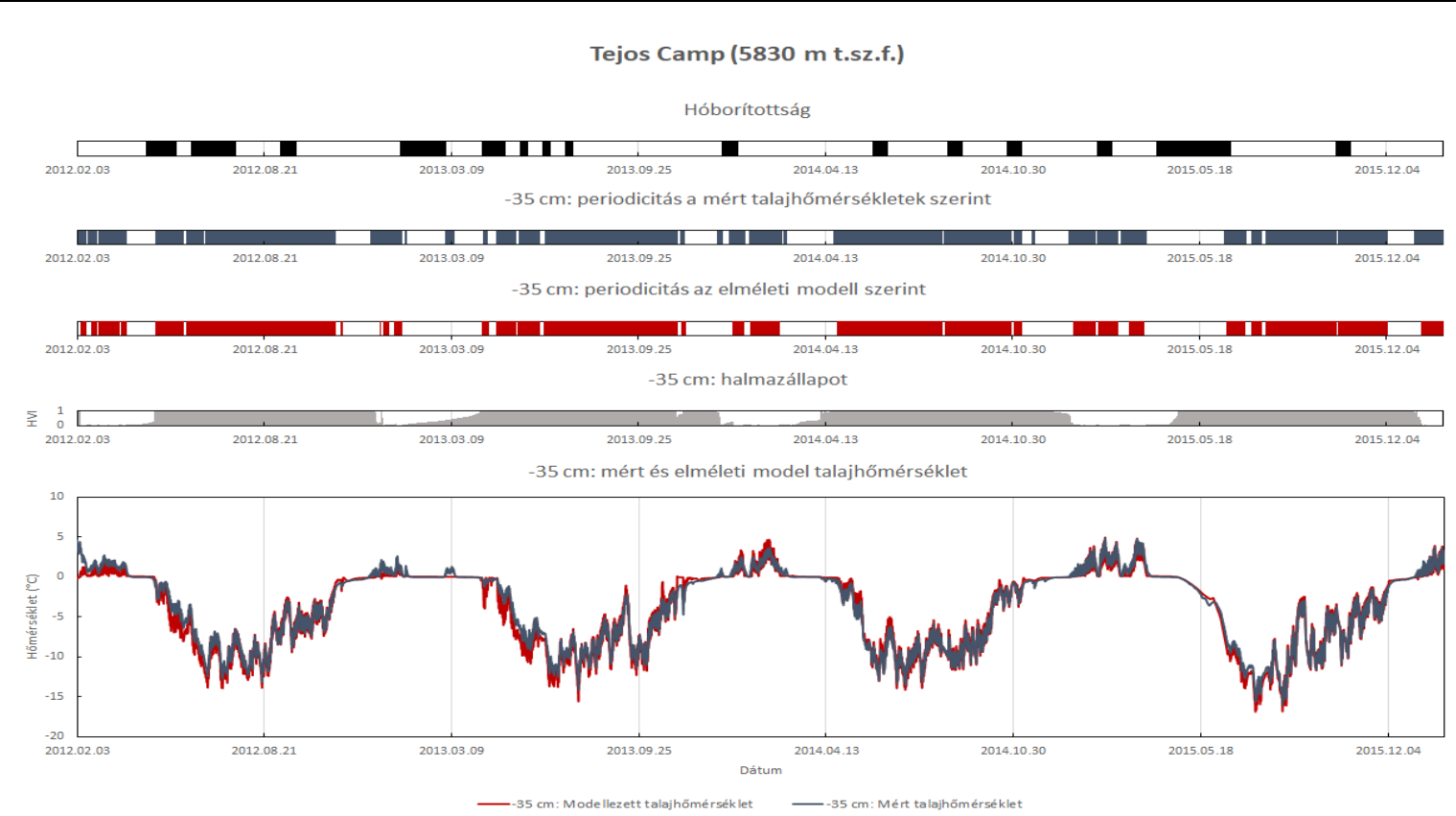

Tejos Camp (5830 m t.sz.f.)

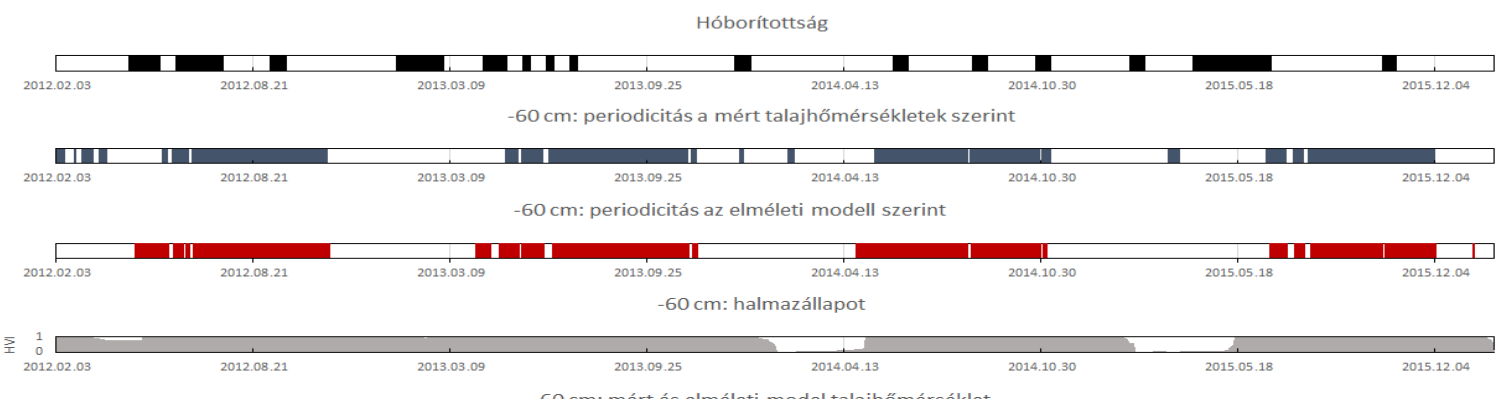

-60 cm: mért és elméleti model talajhómérsékle

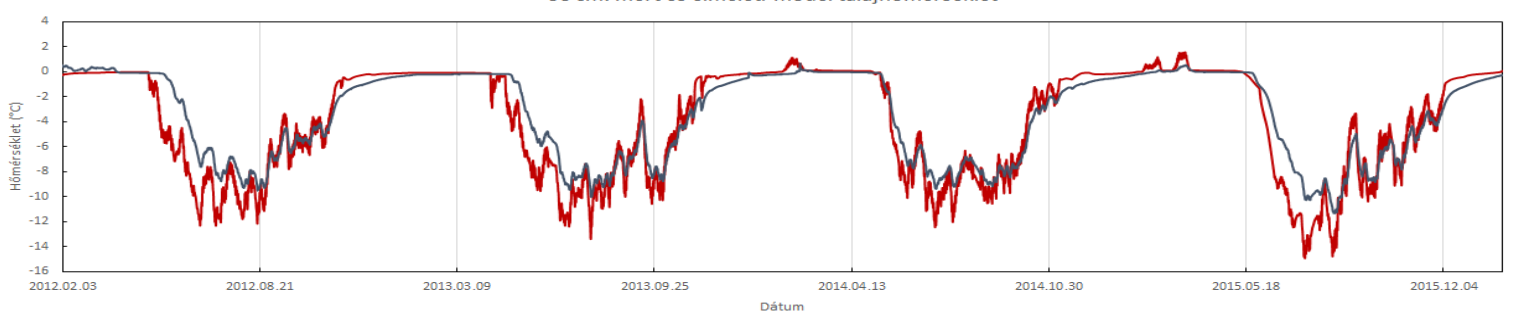

6. ábra: Mérési és modellezési eredmények a Tejos Camp $-35,-60 \mathrm{~cm}$ levő mérőhelyein, hőmérséklet idősorokra, 2012-2016 között. Hófedettség (fekete), napi periodikus viselkedés jelen van (piros: a modellezésből kapott idősorokra, kék: a mért adatokra vonatkozó wavelet spektrum becslés eredménye), modellezett idősorból számított halmazállapot index

(érték: 1, szürke: jég; érték: nulla, fehér: víz) hőmérséklet adatok (piros: modell, kék: mért).

\section{Összegzés}

Vizsgálataink szerint az Ojos del Salado térségében a felszín alatti jég jelenléte valószínütlen $4600 \mathrm{~m}$ t.sz.f. alatt, de valószínü $5300 \mathrm{~m}$ t.sz.f. felett. A pórusjég $5800 \mathrm{~m}$ t.sz.f. magasságban jelen van. 6750 m-en van ugyan permafroszt, de az aktív réteg rendkívül vékony. Eredményeink összhangban vannak az Andok nagyobb magasságaiból származó modellezési (Gruber, 2012) és korábbi in-situ vizsgálatok eredményeivel. Megállapítottuk, hogy az Ojos 
del Saladón jégtartalmú permafroszt 5300-5800 m t.sz.f. magasságban jelenik meg, ami jól illeszkedik e jelenség megjelenési magasságának észak felé emelkedő trendjébe, összhangban az Andok növekvő szárazságával a d. sz. $33.5^{\circ}$ és $27^{\circ}$ között.

Az aktív rétegben fontos és jellemző folyamat a halmazállapot-változás. Ekkor a pórusokban levő víz/jég hőmérséklete eléri a $0{ }^{\circ} \mathrm{C}$-ot, egyensúlyi állapot áll be. A mért hőmérsékletek napi ingadozása alacsonnyá válik, a napos periodikus viselkedés elmarad. A jelenségnek ez utóbbi viselkedését kihasználva wavelet transzformáció alkalmazásával jelentősen lehet segíteni a felszínalatti jég jelenlétére vonatkozó megállapításaink megbízhatóságát.

A wavelet transzformáció alkalmazásának eredményei alapján megállapítható, hogy a mért hőmérséklet idősorokban a napi periódus nemcsak a halmazállapot-változás során marad ki, hanem téltől a nyár felé tartó melegedés során, a felszíntől való távolság függvényében is: $-35 \mathrm{~cm}$-en átlagosan $-1,33{ }^{\circ} \mathrm{C}$-tól, $-60 \mathrm{~cm}$-en átlagosan $-2,53{ }^{\circ} \mathrm{C}$-tól, $0^{\circ} \mathrm{C}$-ig terjedö hőmérséklet intervallumban is. A jelenség megértésére hőtani modell készült a Tejos mintavételi helyszínre, melynek segítségével, a felszíntől számított néhány méteres mélységig becsülni lehetett a jégtartalmú permafroszt hőmérsékletének idő- és térbeli változásait.

A felszíni hőmérsékletváltozás hatására bekövetkező éves hőmérséklet-ingadozás és a napi periodikus változás amplitúdói a felszín alatt a mélység növekedésével csökkennek, aminek mértékét a felső, az adott mérőhely felett lévő réteg anyagának (kőzet, levegő, víz, jég) hőszigetelése és átlagos hőkapacitása befolyásolja, de ezek nagysága az év során változik. Amikor a tavaszi, nyári időszak emelkedő hőmérsékletének hatására elkezdődik a kőzetben levő jég halmazállapotának változása (olvadása), ez a halmazállapot-változás a felszíntől kezdődően különböző mélységekben következik be, függően a külső szezonális hőmérséklet változásától. Mivel a víznek kisebb a hővezető képessége, mint a jégnek, a felszín közelében elhelyezkedő és a jég olvadása miatt egyre növekvő vastagságú porózus kőzet/víz/levegő összetételü réteg egyre nagyobb szigetelő hatást biztosít. Nagyobbat, mint a még meg nem olvadt porózus kőzet/ jég/levegő anyagú. Ennek következménye, hogy a napi periodikus viselkedés meg is szünhet, annak ellenére, hogy adott mélységben - pl. $60 \mathrm{~cm}$-en - a mért hőmérséklet még jóval fagypont alatt van. Mivel télen nincs halmazállapot változás, a felső rétegnek kisebb a szigetelő hatása, ennek következménye, hogy a napi hőmérsékletváltozásból eredő periodikus viselkedés amplitúdói nagyobbak télen, mint nyáron.

A halmazállapot-változás folyamata adott méröhelyen időben aszimmetrikus mintázatot mutat. Ez a jelenség erőteljesen látható a mért felszínalatti hőmérséklet-idősorokban és tükröződik a modell által becsült hőmérsékletértékekben is. A jelenség oka - hasonlóan a napi periodikus viselkedés elmaradásához - az év folyamán változó arányban jelenlévő víz/jég eltérő hőszigetelö képességében rejlik.

Az eredmények szerint, az üledék a felszínhez közel egész évben száraz, a periglaciális felszínformák fejlődése a tanulmányozott mintavételi pontokon gyenge. Ez az erős széllel (Milana, 2009) együtt lehetővé teszi, hogy az eolikus folyamatok felülírják a periglaciális felszínfejlődést - egészen 6000 méteres magasságig. 5000 és $6000 \mathrm{~m}$ t.sz.f. magasságok között, - épp a hatalmas sivatagi fennsíkok, meredek törmeléklejtök és lávafolyások területén egy egyértelmüen elkülöníthető zóna jött így létre, ahol a domborzat fejlödését legfőképp a hideg és a száraz feltételek határozzák meg.

Eredményeink alapján a vizsgált környezetben hosszabb távon a víz - $5300 \mathrm{~m}$ fölött, $\mathrm{kb}$. 6400 m-es magasságig - a felszín alatti jég olvadásából származik. Az olvadékvíz hidrogeológiai szerepe és mennyisége azonban még nem ismert. 


\section{Hivatkozások}

Ahumada, A.L., 2002: Periglacial phenomena in the high mountains of northwestern Argentina. S. Afr. J. Sci., 98: 166-170.

Andrés, N., Palacios, D., Zamorano, J.J., Vázquez-Selem, L., 2011: Shallow Ground Temperatures and Periglacial Processes on Iztaccíhuatl Volcano, Mexico. Permaf. Periglac. Process., 22: 188-194. https://doi.org/10.1002/ppp.713

Aszalós, J.M., Krett, G., Anda, D., Márialigeti, K., Nagy, B., Borsodi, A.K., 2016: Diversity of extremophilic bacteria in the sediment of high-altitude lakes located in the mountain desert of Ojos del Salado volcano, Dry-Andes. Extremophiles. 20(5): 603-620. https://doi.org/10.1007/s00792-016-0849-3

Azócar, G.F., Brenning, A., 2010: Hydrological and Geomorphological Significance of Rock Glaciers in the Dry Andes, Chile $\left(27^{\circ}-33^{\circ} \mathrm{S}\right)$. Permaf. Periglac. Process., 21: 42-53. https://doi.org/10.1002/ppp.669

Azócar, G.F., Brenning, A., Bodin, X., 2017: Permafrost distribution modelling in the semiarid Chilean Andes. Cryosphere, 11: 877-890. https://doi.org/10.5194/tc-11-877-2017

Clapperton, C.M., 1994: The quaternary glaciation of Chile: a review. Revista Chilena de Hist. Nat., 67: 369-383.

Corte, A.E., 1982: Geocriología Argentina general y aplicada. Revista del Instituto de Ciencias Geológicas, 5: 87-120.

Daubechies, I., 1990: The wavelet transform time-frequency localization and signal analysis. IEEE Trans. Inform. Theory, 36: 961-1004. https://doi.org/10.1109/18.57199

Espinoza, J., García, A., Milana, J.P., 2015: Estructura espacial y temporal de las precipitaciones nivales en La Región de Atacama y modelación del aporte hídrico por fusión del manto nival. XIV Congreso Geológico Chileno, La Serena (Chile)

Ginot, P., Kull, C., Schotterer, U., Schwikowski, M., Gäggeler, W.H., 2006: Glacier mass balance reconstruction by sublimation induced enrichment of chemical species on Cerro Tapado (Chilean Andes). Clim. Past, 2: 21-30. https://doi.org/10.5194/cp-2-21-2006

Grab, S.W., Gatebe, C.K., Kinyua, A.M., 2004: Ground thermal profiles from Mount Kenya, East Africa. Geografiska Annaler: Series A, Physical Geography. 86: 131-141. https://doi.org/10.1111/j.0435-3676.2004.00219.x

Grosjean, M., Veit, H., 2005: Water Resources in the Arid Mountains of the Atacama Desert (Northern Chile): Past Climate Changes and Modern Conflicts. In: Huber, U.M., Bugmann, H.K.M. and Reasoner, M.A. eds. Global Change and Mountain Regions: An Overview of Current Knowledge. The Netherlands: Springer Netherlands. pp. 93-104. https://doi.org/10.1007/1-4020-3508-X 10

Gruber, S., 2012: Derivation and analysis of a high-resolution estimate of global permafrost zonation. Cryosphere, 6: 221-233. https://doi.org/10.5194/tc-6-221-2012

Hanson, S., Hoelzle, M., 2004: The thermal regime of the active layer at the Murtèl rock glacier based on data from 2002. Permaf. Periglac. Process., 15: 273-282. https://doi.org/10.1002/ppp.499

Happoldt, H., Schrott, L., 1992: A Note on Ground Thermal Regimes and Global Solar Radiation at $4720 \mathrm{~m}$ a.s.1., High Andes of Argentina. Permaf. Periglac. Process., 3: 241-245. https://doi.org/10.1002/ppp.3430030312

Harris, S.A., Brown, R.J.E., 1978: Plateau mountain: a case study of alpine permafrost in the Canadian Rocky Mountains. Proceedings 3rd International Conference on Permafrost, Edmonton, Alberta. 1: 385-391.

Houston, J., Hartley, A.J., 2003: The central Andean west-slope rainshadow and its potential contribution to the origin of hyper-aridity in the Atacama Desert. Int. J. Climatol., 23: 1453-1464. https://doi.org/10.1002/joc.938 
Houston, J., 2006: Evaporation in the Atacama Desert: An empirical study of spatio-temporal variations and their causes. J. Hydrol., 330: 402-412. https://doi.org/10.1016/j.jhydrol.2006.03.036

Ishikawa, M., 2003: Thermal regimes at the snow-ground interface and their implications for permafrost investigation. Geomorphology, 52: 105-120. https://doi.org/10.1016/S0169555X(02)00251-9

Kovács, J., Hatvani, I.G., Korponai, J., Kovács, I.S., 2010: Morlet wavelet and autocorrelation analysis of long-term data series of the Kis-Balaton water protection system (KBWPS). Ecological Engineering, 36(10): 1469-1477. https://doi.org/10.1016/j.ecoleng.2010.06.028

Kull, C., Grosjean, M., Veit, H., 2002: Modelling modern and Late Pleistocene glacioclimatological conditions in the North Chilean Andes (29-30 ${ }^{\circ}$ S). Clim. Change, 52: 359-381. https://doi.org/10.1023/A:1013746917257

Li, R., Zhao, L., Wu, T., Ding, Y., Xiao, Y., Hu, G., Zou, D., Li, W., Yu, W., Jiao, Y., Qin, Y., 2014: The impact of surface energy exchange on the thawing process of active layer over the northern Qinghai-Xizang Plateau, China. Environ. Earth Sci., 72(6): 2091-2099. https://doi.org/10.1007/s12665-014-3117-9

Messerli, B., Grosjean, M., Vuille, M., 1997: Water availability, protected areas, and natural resources in the Andean desert Altiplano. Mountain Research and Development. 17(3): 229-238. https://doi.org/10.2307/3673850

Milana, J.P., 2009: Largest wind ripples on Earth? Geology, 37(4): 343-346. https://doi.org/10.1130/G25382A.1

Otto, J.C., Keuschnig, M., Götz, J., Marbach, M., Schrott, L., 2012: Detection of mountain permafrost by combining high resolution surface and subsurface information - an example from the Glatzbach catchment, Austrian Alps. Geografiska Annaler: Series A, Physical Geography, 94: 43-57. https://doi.org/10.1111/j.1468-0459.2012.00455.x

Romanovsky, E.V., Osterkamp, E.T., 2000: Effects of unfrozen water on heat and mass transport processes in the active layer and permafrost. Permaf. Periglac. Process., 11: 219-239.

https://doi.org/10.1002/1099-1530(200007/09)11:3<219::AIDPPP352>3.0.CO;2-7

Schrott, L., 1991: Global solar radiation, Soil Temperature and Permafrost in the Central Andes, Argentina: a Progress Report. Permaf. Periglac. Process., 2: 59-66. https://doi.org/10.1002/ppp.3430020110

Schröder, H., Schmidt, D., 2000: Morfología climática y morfogénesis del Volcán Llullaillaco (Chile/Argentina). Revista de Geografía Norte Grande, 27: 69-92.

Torrence, C., Compo, G.P., 1998: A practical guide to wavelet analysis. Bull. Am. Meteor. Soc., 79: 61-78. https://doi.org/10.1175/1520-0477(1998)079<0061:APGTWA>2.0.CO;2

Trombotto, D., 2000: Survey of cryogenic processes, periglacial forms and permafrost conditions in South America. Revista do Instituto Geológico, São Paolo, 21(1/2): 33-55. https://doi.org/10.5935/0100-929X.20000004

van Everdingen, $R$. ed., 2005: Multi-language glossary of permafrost and related ground-ice terms. Boulder, CO: National Snow and Ice Data Center/World Data Center for Glaciology.

Vuille, M., Ammann, C., 1997: Regional snowfall patterns in the high, arid Andes. Clim. Change, 36: 413-423. https://doi.org/10.1023/A:1005330802974 